\title{
Effect of past and present lifestyle habits and nutrition on calcaneal quantitative osteo-sono index in pre- and post-menopausal females
}

\author{
Masakatsu Nakada ${ }^{1}$, Shinichi Demura ${ }^{2}$ \\ ${ }^{1}$ National Defense Academy, Kanagawa, Japan; nakada@nda.ac.jp \\ ${ }^{2}$ Graduate school of Natural Science \& Technology, Kanazawa University, Kanazawa, Japan
}

Received 4 November 2009; revised 14 December 2009; accepted 17 December 2009.

\begin{abstract}
This study is examined the effect of past and present lifestyle habits and nutrition on the osteo-sono assessment index (OSI) in pre- and post-menopausal females. The subjects were 200 premenopausal females $(38.8 \pm 10.3$ years $)$ and 156 postmenopausal females $(59.2 \pm 5.9$ years). BMD (Body mineral density) was estimated by right-calcaneal OSI using an ultrasonic transmission method with an AOS-100 device (ALOKA). The number of postmenopau- sal females in the close examination and guidance required groups (80 cases: $51.3 \%$ ) $(\mathrm{OSI}<2.428)$ was significantly higher than that of premenopausal females (44 cases: $22.0 \%)\left(x^{2}=33.105\right.$ : $P<0.000$ ).

In premenopausal females, the proportion of subjects that had not taken vitamin $D$ in the past (in junior high school and high school) was significantly higher in the close examinationguidance required group (OSI < 2.428) than in the normal group (OSI $\geqq 2.428$ ). However, in postmenopausal females, there was no significant difference in past and present lifestyle habits and nutrition between the close examination-guidance required group and the normal group. In premenopausal females, it was determined that the intake of vitamin $D$ during puberty increased the absorption of calcium significantly.
\end{abstract}

Keywords: Lifestyle and Nutrition Habits, Osteo-Sono Assessment Index, Pre and Postmenopausal Females

\section{INTRODUCTION}

The occurrence of osteoporosis with bone-thinning and brittle bones is high in elderly people [1-3]. The complications of fractures limit daily activities (ADL) and re- duce the quality of life (QOL) of the affected individuals [4-6]. Even when the level of bone loss is below normal (osteopenia), the risk of fractures is high [5]. Females in particular are prone to have osteoporosis and should pay particular attention to the increased risk of a nutritionally deficient diet $[6,7]$.

On the other hand, the significance of healthy eating habits in addition to exercise to maintain and increase BMD has been established [1,8]. In females, bone mass increases during puberty with skeletal growth and peaks from the late teens into the twenties. Afterwards, bone mass is merely maintained from the late thirties to early forties $[5,6]$. Bone mass density peaks during youth. Increased BMD through proper nutrition, exercise, exposure to sun, etc. are all effective measures for preventing osteoporosis [2]. Hence, it will be necessary to correlate not only present conditions, but also life style habits during youth. Aging is a significant factor which affects BMD. However, the effects of lifestyle habits (the amount of sleep and alcohol consumption, etc.) and nutrition on the bone mineral density in females have been studied specifically in elderly people and young students $[1,2,7,9,10]$. However, the effects of lifestyle habits should be researched for people of a wider age range. On the other hand, the bone mass of postmenopausal females decreases markedly with a rapid decline in estrogen levels [11]. Hence, studies on the BMD in females should be considered from the onset of menopause. This study examined the effects of past and present lifestyle habits and nutrition on the osteo-sono assessment index (OSI) in pre- and post-menopausal females from age 20 to 70 .

\section{METHODS}

\subsection{Subjects}

Subjects were 200 premenopausal females $(38.8 \pm 10.3$ years) and 156 postmenopausal females ( $59.2 \pm 5.9$ years) Table 1 shows the number of subjects, and their mean heights and weights, at each age level. Written informed consent was obtained from all subjects after a full ex- 
planation of the experimental purpose and protocol.

\subsection{Measurement of Osteo-Sono Assessment Index (OSI) and Setting of OSI Group}

BMD was estimated by the right-calcaneus using an ultrasonic transmission method with an AOS-100 device (ALOKA). The calcaneal osteo-sono assesment used the osteo-sono assesment index (OSI: $\mathrm{TI} \times \mathrm{SOS}^{2}$ ) by calculating speed of sound (SOS) of ultrasonic transmission in the calcaneus and the transmission index (TI) as described previously $[12,13]$.

The quantitative assessment of bones has generally been performed by Dual X-ray absorptiometry (DXA) and quantitative ultrasound (QUS) [14]. The DXA can measure the total body bone mineral density and is mainly used for precise measurement after screening tests [5]. The QUS is very practical and safe without the effects of radiation [5]. The OSI by AOS-100 has high reliability [14]. Thus, this study used an AOS-100 by QUS. The Japan Osteoporosis Foundation [5] classified females into a close examination (OSI $<80 \%$ of an average OSI $=$ $2.158)$, a guidance required group $(2.158 \leqq$ OSI $<90 \%$ of an average OSI $=2.428)$ and a normal group (OSI $\geqq$ $2.428)$ based on an average OSI (OSI $=2.698)$ of females between 20 and 44 years old by osteo-sono assessment criteria. In this study, we combined the former two groups considering a sample size of each age level and compared the close examination and guidance required group (OSI $<2.428$ ) with the normal group (OSI $\geqq 2.428$ ).

\subsection{Lifestyle and Nutrition Habits Questionnaire}

At present, factors found to be involved in BMD by a large-scale prospective cohort study (Japanese Population-Based Osteoporosis (JPOS) Study) have been examined $[15,16]$. These prospective cohort studies have the advantage of being prospectively able to measure the predictor, but also require considerable time [17]. The present study is equivalent to a retrospective cohort study [17] and while recall bias may affect the conclusions, useful findings can be identified at an earlier stage.

The study evaluated past and present lifestyle habits and nutrition by questionnaires. The survey was carried out just before a measurement of OSI. Naka et al. [2] selected menopause, regular milk consumption, intensity of physical exercise, and awareness of eating habits and physical activity as lifestyle habits. Tomita selected breakfast habits and regular consumption of milk and dairy products, fish and shellfish, meat products etc. during childhood and later years (about 6-15 yr) as well as eating habits. Elgán et al. [18] selected 10 items (dietary habits (i.e. sugar, fat, fiber, and fruit and vegetables), physical activity, smoking habits, alcohol consumption,
Table 1. Physique of subjects.

\begin{tabular}{cccccc}
\hline & \multicolumn{2}{c}{ Height $(\mathrm{cm})$} & \multicolumn{2}{c}{ Weight $(\mathrm{kg})$} \\
& $\mathrm{N}$ & Mean & SD & Mean & SD \\
\hline $20 \mathrm{~s}$ & 44 & 161.0 & 5.0 & 53.8 & 5.5 \\
$30 \mathrm{~s}$ & 61 & 158.8 & 5.2 & 53.4 & 7.2 \\
$40 \mathrm{~s}$ & 76 & 158.3 & 5.2 & 53.9 & 8.1 \\
$50 \mathrm{~s}$ & 104 & 156.6 & 4.8 & 54.2 & 6.5 \\
$60 \mathrm{~s}$ & 62 & 154.7 & 5.7 & 52.8 & 7.9 \\
$70 \mathrm{~s}$ & 9 & 152.3 & 4.2 & 52.3 & 6.6 \\
\hline
\end{tabular}

time spent outdoors etc.) as lifestyle habits. The Japan Osteoporosis Foundation [5] coffee, milk, dairy products, fish, meat, soy products, green and yellow vegetables, and natto as meal and articles of taste items for their interview sheet. Referring to the above, this study selected the following 9 items to investigate present eating habits: (1) sleep duration, (2) frequency of alcohol consumption, (3) smoking habits, (4) intervals without meals, (5) regular consumption of dairy products (milk, cheese, yogurt, etc.), (6) intake of calcium supplements, (7) intake of vitamin D (fish, chicken egg, fungi), (8) intake of instant food (instant noodles, instant coffee, etc.), and (9) frequency and length of exposure to sun.

The agreement rates of 9 question items by the testretest method of 59 subjects ranged from $0.559-0.983$. Their $\kappa$ coefficients [19] ranged from $0.287(\mathrm{P}=0.010)$ $0.890(\mathrm{P}=0.000)$ and any value was significant. As stated, the subjects' past lifestyle habit (in junior high school and high school) regarding (1) amount of sleep, (2) intervals without meals, (3) intake of dairy products, (4) intake of vitamin $\mathrm{D}$, and (5) intake of instant food were among the above 9 items surveyed.

\subsubsection{Data Analysis}

Both groups were classified into pre- and post-menopausal females, cross tabulations of the frequency of past and present lifestyle habits and nutrition were made, and then independent tests were performed. When a significant difference emerged, residual analysis was used. A probability level of 0.05 was indicated statistical significance.

\section{RESULTS}

Figure 1 show the results of the osteo-sono assessment index (OSI). The number of postmenopausal females in the close examination and guidance required groups (OSI $<2.428$ ) was significantly higher than that (44 cases: $22.0 \%)$ of premenopausal females $\left(\chi^{2}=33.105\right.$ : $\left.\mathrm{P}<0.000\right)$. The number of people in the close examination and guidance required groups increased with age, particularly in people 50 years and older.

Table 2 (premenopausal females) and Table 3 (postmenopausal females) show cross tabulations by the fre- 
Table 2. Present lifestyle and nutrition habits and the OSI of premenopausal females.

\begin{tabular}{|c|c|c|c|c|c|c|c|c|}
\hline \multicolumn{2}{|l|}{ Sleeping time } & $\begin{array}{l}\text { Less than } \\
6 \text { hours }\end{array}$ & $\begin{array}{l}\text { More than } 6 \\
\text { hours - less } \\
\text { than } 7 \text { hours }\end{array}$ & $\begin{array}{l}\text { More than } 7 \\
\text { hours - less } \\
\text { than } 8 \text { hours }\end{array}$ & $\begin{array}{c}\text { More than } 8 \\
\text { hours }\end{array}$ & $\chi^{2}$ & $\mathrm{p}$ & $\phi$ \\
\hline \multirow{2}{*}{ Result of O SI } & CEGR & $10(-1.04)$ & $29(2.39)$ & $4(-2.05)$ & $10.96)$ & 7.891 & $0.048 *$ & 0.20 \\
\hline & Normal & $48(1.04)$ & $71(-2.39)$ & 36 (2.05) & $1(-0.96)$ & & & \\
\hline \multicolumn{2}{|l|}{ Alcohol intake } & No & $\begin{array}{c}1 \text { - } 3 \text { times a } \\
\text { month }\end{array}$ & $\begin{array}{c}1 \text { - } 3 \text { times a } \\
\text { week }\end{array}$ & $\begin{array}{c}\text { nearly every } \\
\text { day }\end{array}$ & & & \\
\hline \multirow{2}{*}{ Result of 0 SI } & CEGR & 19 & 8 & 6 & 10 & 7.76 & 0.051 & 0.20 \\
\hline & Normal & 50 & 62 & 22 & 21 & & & \\
\hline \multicolumn{2}{|l|}{ Smoking } & No & Have a habit & Quit & & & & \\
\hline \multirow{2}{*}{ Result of 0 SI } & CEGR & 35 & 4 & 5 & & 0.602 & 0.74 & 0.06 \\
\hline & Normal & 127 & 16 & 12 & & & & \\
\hline \multicolumn{2}{|l|}{ Skip a meal } & No & Breakfast & Lunch & Supper & & & \\
\hline \multirow{2}{*}{ Result of O SI } & CEGR & 35 & 5 & 0 & 0 & 1.664 & 0.645 & 0.09 \\
\hline & Normal & 125 & 18 & 2 & 4 & & & \\
\hline \multicolumn{2}{|c|}{ Intake of dairy prodets } & No & $\begin{array}{c}1-3 \text { times a } \\
\text { month }\end{array}$ & $\begin{array}{c}4-7 \text { times a } \\
\text { week } \\
\end{array}$ & & & & \\
\hline \multirow{2}{*}{ Result of 0 SI } & CEGR & 3 & 20 & 21 & & 0.63 & 0.73 & 0.06 \\
\hline & Normal & 15 & 62 & 79 & & & & \\
\hline \multicolumn{2}{|c|}{ Intake of Ca supplement } & No & Rarely & Continuous & & & & \\
\hline \multirow{2}{*}{ Result of O SI } & CEGR & 33 & 7 & 3 & & 0.564 & 0.754 & 0.05 \\
\hline & Normal & 110 & 31 & 14 & & & & \\
\hline \multicolumn{2}{|c|}{ Intake of vitamin D } & No & $\begin{array}{c}1 \text { - } 3 \text { times a } \\
\text { week }\end{array}$ & $\begin{array}{c}4-7 \text { times a } \\
\text { week }\end{array}$ & & & & \\
\hline \multirow{2}{*}{ Result of 0 SI } & CEGR & 5 & 25 & 14 & & 2.200 & 0.333 & 0.11 \\
\hline & Normal & 8 & 94 & 54 & & & & \\
\hline \multicolumn{2}{|c|}{ Intake of instant food } & No & $\begin{array}{c}1-3 \text { times a } \\
\text { month }\end{array}$ & $\begin{array}{c}\text { More than } \\
\text { once a week }\end{array}$ & & & & \\
\hline \multirow{2}{*}{ Result of 0 SI } & CEGR & 5 & 14 & 25 & & 1.816 & 0.403 & 0.10 \\
\hline & Normal & 27 & 56 & 71 & & & & \\
\hline \multicolumn{2}{|l|}{ Sunbathing } & No & $\begin{array}{c}1 \text { - } 3 \text { times a } \\
\text { week }\end{array}$ & $\begin{array}{l}\text { More than } 4 \\
\text { times a week }\end{array}$ & & & & \\
\hline \multirow{2}{*}{ Result of O SI } & CEGR & 14 & 15 & 15 & & 1.557 & 0.459 & 0.09 \\
\hline & Normal & 39 & 68 & 46 & & & & \\
\hline
\end{tabular}

Note)CEGR:close examination or guidance required group, ${ }^{*}: \mathrm{P}<0.05$,

Number shown in parenthese is the $\mathrm{Z}$ score of residual analysis.

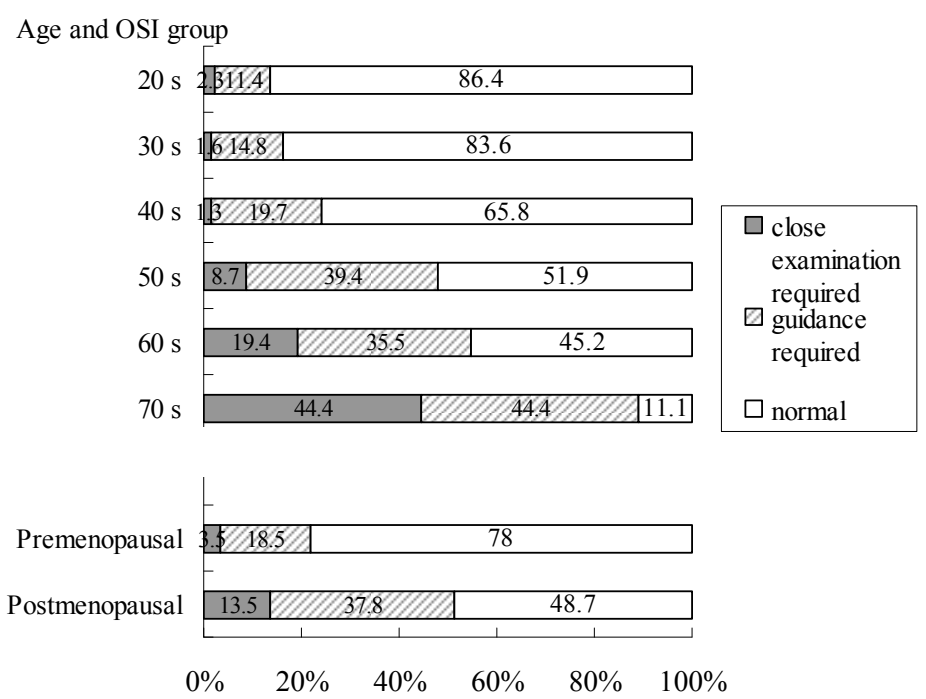

Figure 1. Result of osteo-sono assessment index (OSI).

ency of OSI groups and the frequency of present lifestyle habits and nutrition. An independent test showed sig- 
nificant differences in the amount of sleep in the premenopausal group of females. However, the results of residual analysis showed no significant differences in any category. In postmenopausal females, there was no significant difference in any present lifestyle habits or nutrition.

Table 4 (premenopausal females) and Table 5 (postmenopausal females) show cross tabulations by the frequency of OSI groups and past lifestyle habits and nutrition (in junior high school and high school). An independent test showed significant differences in the amount of sleep and intake of vitamin D in the group of premenopausal females. The results of residual analysis showed significant differences in the intake of vitamin D, and there was a higher proportion of subjects taking no vitamin $\mathrm{D}$ in the close examination-guidance required group $(z=2.77>2.64: p<0.05)$. In postmenopausal females, there was no significant difference in past lifestyle habits and nutrition.

\section{DISCUSSION}

The Japan Osteoporosis Foundation [5] set the level for close examination (OSI <2.158) when using an AOS-100 device (ALOKA) as $0.8-1.0 \%$ in people 40 -year olds, and $5.2-11.4 \%$ in 50-year olds. In this study, they were respectively $1.3 \%$ and $8.7 \%$. Hence, the level for close examination was considered to be standard.

There were no differences in present lifestyle habits and nutrition by OSI level. Nutrition and eating habits in addition to exercise habits are important for maintaining and increasing BMD. Principal minerals for absorption of calcium are magnesium and Vitamin D [7]. We surveyed past and present consumption of dairy products and vitamin D excluding magnesium and present intake of calcium supplements. Lloyd et al. [20] reported that by increasing daily calcium intake from $80 \%$ of the recommended daily allowance to $110 \%$ via supplementation with calcium citrate malate resulted in significant increases in total body and spinal bone density in adolescent girls. The proportion of those test subjects taking no vitamin D (fish, chicken egg, fungi etc) was higher in the close examination-guidance required group than in the normal group. The considerable amount of time that elderly people spend indoors also decreases Vitamin D synthesis through the skin in addition to their intake of vitamin D [5]. Dawson-Hughes et al. [21] examined during a long-term (3-year) study that the proper intake of vitamin $\mathrm{D}$ with intake of calcium helps reduce the decrease of BMD. Intake of sufficient calcium and vitamin $\mathrm{D}$ additionally promotes the absorption of calcium in the small intestines, maintains calcitriol in the blood, and prevents an increased parathyroid hormone (PTH) level. This contributes to a reduction of bone loss $[5,21]$. The absorption of calcium is supported by the intake of vitamin D during puberty (junior high school and high school age) which increases bone mass with skeletal growth which may be very important for increasing peak bone mass.

On the other hand, there was no difference in the past or present lifestyle habits and nutrition in postmenopausal females between the close examination and guidance required groups and the normal group. Bone mass decreases with age at the rate of about $3 \%$ a year through a lack of estrogen even in normal postmenopausal females [22]. Elderly people may need to increase their daily requirement of calcium as their intestinal calcium absorption decreases [23]. Hence, with increasing age and lack of estrogen, the bone metabolism of postmenopausal females is largely affected, thus obscuring the effect of past and present life habits on bone mass changes. In addition, because of the long interval since puberty for postmenopausal females, subsequent lifestyle habits (eating habits and exercise) may have a greater affect on BMD. Hence, a long-term study should be done considering the BMD of youth.

This study did not examine the effect of exercise stimulus. Sanada et al. [24] reportedly showed a significant relationship between calcaneal bone strength and the strength of triceps muscle in postmenopausal females. Bone mass increases by imposing the load of body mass on the lumbar spine. Thus, the bone structure of the lower limbs and thereby the bones of the upper and lower limbs and spine benefit from the mechanical muscle stimulus received from twisting, distortion, and towing. Therefore, BMD is the result of past and present exercise and lifestyle habits.

\section{SUMMARY}

This study examined the effect of past and present lifestyle habits and nutrition on OSI in pre- and postmenopausal females from 20 to 70 years of age.

1) The number of postmenopausal females in the close examination and guidance required groups (80 cases: $51.3 \%)(\mathrm{OSI}<2.428)$ was significantly higher than that of premenopausal females (44 cases: $22.0 \%)\left(\chi^{2}=33.105\right.$ : $\mathrm{P}<0.000)$.

2) In premenopausal females, the number of subjects who had not taken vitamin D in the past (in junior high school and high school) was significantly higher in a close examination-guidance required group (OSI < 2.428) than in the normal group (OSI $\geqq 2.428$ ). However, in postmenopausal females, there was no significant difference in past and present lifestyle habits and nutrition between the two groups.

3) In premenopausal females, it was inferred that increased intake of vitamin D during puberty is important to increase the absorption of calcium. 
Table 3. Present lifestyle and nutrition habits and the OSI of postmenopausal females.

\begin{tabular}{|c|c|c|c|c|c|c|c|c|}
\hline \multicolumn{2}{|l|}{ Sleeping time } & $\begin{array}{l}\text { Less than } \\
6 \text { hours }\end{array}$ & $\begin{array}{l}\text { More than } 6 \\
\text { hours - less } \\
\text { than } 7 \text { hours }\end{array}$ & $\begin{array}{l}\text { More than } 7 \\
\text { hours - less } \\
\text { than } 8 \text { hours }\end{array}$ & $\begin{array}{c}\text { More than } 8 \\
\text { hours }\end{array}$ & $\chi^{2}$ & $\mathrm{p}$ & $\phi$ \\
\hline \multirow{2}{*}{ Result of O SI } & CEGR & 22 & 37 & 17 & 4 & 1.330 & 0.722 & 0.09 \\
\hline & Normal & 17 & 38 & 19 & 2 & & & \\
\hline \multicolumn{2}{|l|}{ Alcohol intake } & No & $\begin{array}{c}1-3 \text { times a } \\
\text { month }\end{array}$ & $\begin{array}{c}1 \text { - } 3 \text { times a } \\
\text { week }\end{array}$ & $\begin{array}{c}\text { nearly every } \\
\text { day }\end{array}$ & & & \\
\hline \multirow{2}{*}{ Result of O SI } & CEGR & 44 & 16 & 8 & 11 & 3.907 & 0.272 & 0.16 \\
\hline & Normal & 43 & 8 & 8 & 17 & & & \\
\hline \multicolumn{2}{|l|}{ Smoking } & No & Have a habit & Quit & & & & \\
\hline \multirow{2}{*}{ Result of O SI } & CEGR & 68 & 7 & 4 & & 1.028 & 0.598 & 0.08 \\
\hline & Normal & 63 & 6 & 7 & & & & \\
\hline \multicolumn{2}{|l|}{ Skip a meal } & No & Breakfast & Lunch & Supper & & & \\
\hline \multirow{2}{*}{ Result of O SI } & CEGR & 71 & 3 & 3 & 0 & 1.942 & 0.584 & 0.12 \\
\hline & Normal & 66 & 3 & 1 & 1 & & & \\
\hline \multicolumn{2}{|c|}{ Intake of dairy prodets } & No & $\begin{array}{c}1-3 \text { times a } \\
\text { month }\end{array}$ & $\begin{array}{c}4-7 \text { times a } \\
\text { week }\end{array}$ & & & & \\
\hline \multirow{2}{*}{ Result of O SI } & CEGR & 4 & 29 & 45 & & 1.001 & 0.606 & 0.08 \\
\hline & Normal & 2 & 25 & 48 & & & & \\
\hline \multicolumn{2}{|c|}{ Intake of Ca supplement } & No & Rarely & Continuous & & & & \\
\hline \multirow{2}{*}{ Result of O SI } & CEGR & 57 & 11 & 10 & & 2.349 & 0.309 & 0.12 \\
\hline & Normal & 60 & 5 & 11 & & & & \\
\hline \multicolumn{2}{|c|}{ Intake of vitamin $D$} & No & $\begin{array}{c}1 \text { - } 3 \text { times a } \\
\text { week }\end{array}$ & $\begin{array}{c}4-7 \text { times a } \\
\text { week }\end{array}$ & & & & \\
\hline \multirow{2}{*}{ Result of O SI } & CEGR & 7 & 40 & 32 & & 0.012 & 0.994 & 0.01 \\
\hline & Normal & 7 & 38 & 30 & & & & \\
\hline \multicolumn{2}{|c|}{ Intake of instant food } & No & $\begin{array}{c}1-3 \text { times a } \\
\text { month }\end{array}$ & $\begin{array}{c}\text { More than } \\
\text { once a week }\end{array}$ & & & & \\
\hline \multirow{2}{*}{ Result of O SI } & CEGR & 21 & 24 & 33 & & 2.787 & 0.248 & 0.14 \\
\hline & Normal & 27 & 24 & 22 & & & & \\
\hline \multicolumn{2}{|l|}{ Sunbathing } & No & $\begin{array}{c}1 \text { - } 3 \text { times a } \\
\text { week }\end{array}$ & $\begin{array}{l}\text { More than } 4 \\
\text { times a week }\end{array}$ & & & & \\
\hline \multirow{2}{*}{ Result of O SI } & CEGR & 12 & 31 & 30 & & 2.534 & 0.282 & 0.13 \\
\hline & Normal & 10 & 23 & 39 & & & & \\
\hline
\end{tabular}

Table 4. Past lifestyle and nutrition and the OSI of premenopausal females.

\begin{tabular}{|c|c|c|c|c|c|c|c|c|}
\hline \multicolumn{2}{|l|}{ Sleeping time } & $\begin{array}{l}\text { Less than } \\
6 \text { hours }\end{array}$ & $\begin{array}{l}\text { More than } 6 \\
\text { hours - less } \\
\text { than } 7 \text { hours }\end{array}$ & $\begin{array}{l}\text { More than } 7 \\
\text { hours - less } \\
\text { than } 8 \text { hours }\end{array}$ & $\begin{array}{c}\text { More than } 8 \\
\text { hours }\end{array}$ & $\chi^{2}$ & $\mathrm{p}$ & $\phi$ \\
\hline \multirow{2}{*}{ Result of 0 SI } & CEGR & $1(-1.96)$ & $10(-0.89)$ & $15(0.87)$ & $7(2.16)$ & 8.471 & $0.037 *$ & 0.23 \\
\hline & Normal & $20(1.96)$ & $48(0.89)$ & $46(-0.87)$ & $10(-2.16)$ & & & \\
\hline \multicolumn{2}{|l|}{ Skip a meal } & No & Breakfast & Lunch & Supper & & & \\
\hline \multirow{2}{*}{ Result of 0 SI } & CEGR & 32 & 5 & 0 & 0 & 1.225 & 0.268 & 0.08 \\
\hline & Normal & 112 & 31 & 0 & 0 & & & \\
\hline \multicolumn{2}{|c|}{ Intake of dairy prodets } & No & $\begin{array}{c}1-3 \text { times a } \\
\text { month }\end{array}$ & $\begin{array}{c}4-7 \text { times a } \\
\text { week }\end{array}$ & & & & \\
\hline \multirow{2}{*}{ Result of 0 SI } & CEGR & 4 & 20 & 14 & & 1.825 & 0.402 & 0.10 \\
\hline & Normal & 16 & 61 & 72 & & & & \\
\hline \multicolumn{2}{|c|}{ Intake of vitamin D } & No & $\begin{array}{c}1 \text { - } 3 \text { times a } \\
\text { week }\end{array}$ & $\begin{array}{c}4-7 \text { times a } \\
\text { week }\end{array}$ & & & & \\
\hline \multirow{2}{*}{ Result of O SI } & CEGR & $5\left(2.77^{*}\right)$ & $22(0.17)$ & $8(-1.47)$ & & 8.712 & $0.013 *$ & 0.22 \\
\hline & Normal & $4(-2.77 *)$ & $87(-0.17)$ & $51(1.47)$ & & & & \\
\hline \multicolumn{2}{|c|}{ Intake of instant food } & No & $\begin{array}{c}1-3 \text { times a } \\
\text { month }\end{array}$ & $\begin{array}{c}\text { More than } \\
\text { once a week }\end{array}$ & & & & \\
\hline \multirow{2}{*}{ Result of 0 SI } & CEGR & 7 & 19 & 8 & & 0.710 & 0.701 & 0.06 \\
\hline & Normal & 24 & 79 & 44 & & & & \\
\hline
\end{tabular}

Note)CEGR:close examination or guidance required group, ${ }^{*}: \mathrm{P}<0.05$,

Number shown in parentheses is the $\mathrm{Z}$ score of the residual analysis 
Table 5. Past lifestyle and nutrition habits and the OSI of postmenopausal females.

\begin{tabular}{|c|c|c|c|c|c|c|c|c|}
\hline Sleeping time & & $\begin{array}{c}\text { Less than } \\
6 \text { hours }\end{array}$ & $\begin{array}{l}\text { More than } 6 \\
\text { hours - less } \\
\text { than } 7 \text { hours }\end{array}$ & $\begin{array}{l}\text { More than } 7 \\
\text { hours - less } \\
\text { than } 8 \text { hours }\end{array}$ & $\begin{array}{c}\text { More than } 8 \\
\text { hours }\end{array}$ & $\chi^{2}$ & $\mathrm{p}$ & $\phi$ \\
\hline \multirow{2}{*}{ Result of O SI } & CEGR & 4 & 24 & 23 & 9 & 0.891 & 0.828 & 0.09 \\
\hline & Normal & 6 & 20 & 25 & 10 & & & \\
\hline \multicolumn{2}{|l|}{ Skip a meal } & No & Breakfast & Lunch & Supper & & & \\
\hline \multirow{2}{*}{ Result of 0 SI } & CEGR & 55 & 8 & 2 & 0 & 2.527 & 0.283 & 0.14 \\
\hline & Normal & 52 & 11 & 0 & 0 & & & \\
\hline \multicolumn{2}{|c|}{ Intake of dairy prodets } & No & $\begin{array}{c}1-3 \text { times a } \\
\text { month }\end{array}$ & $\begin{array}{c}4-7 \text { times a } \\
\text { week }\end{array}$ & & & & \\
\hline \multirow{2}{*}{ Result of O SI } & CEGR & 15 & 39 & 10 & & 2.937 & 0.230 & 0.15 \\
\hline & Normal & 13 & 36 & 19 & & & & \\
\hline \multicolumn{2}{|c|}{ Intake of vitamin D } & No & $\begin{array}{c}1-3 \text { times a } \\
\text { month }\end{array}$ & $\begin{array}{c}\begin{array}{c}-7 \text { times a } \\
\text { week }\end{array} \\
\end{array}$ & & & & \\
\hline \multirow{2}{*}{ Result of 0 SI } & CEGR & 7 & 40 & 15 & & 1.946 & 0.378 & 0.12 \\
\hline & Normal & 5 & 38 & 23 & & & & \\
\hline \multicolumn{2}{|c|}{ Intake of instant food } & No & $\begin{array}{c}1-3 \text { times a } \\
\text { month }\end{array}$ & $\begin{array}{c}\text { More than } \\
\text { once a week }\end{array}$ & & & & \\
\hline \multirow{2}{*}{ Result of O SI } & CEGR & 25 & 27 & 10 & & 0.203 & 0.904 & 0.04 \\
\hline & Normal & 24 & 29 & 12 & & & & \\
\hline
\end{tabular}

\section{REFERENCES}

[1] Hirota, T., Nara, M., Ohguri, M., Manago, E. and Hirota, K. (1992) Effect of diet and lifestyle on bone mass in Asian young women. The American Journal of Clinical Nutrition, 55, 1168-1173.

[2] Naka, T., Nakajima, D., Oh, T.W., Han, I., Sakurai, T. and Igawa, S. (2004) Effects of lifestyle on bone metabolism in middle-aged and aged Japanese women. Japanese Journal of Physiological Anthropology, 9, 1-8.

[3] Rusoff, L.L. (1987) Calcium--osteoporosis and blood pressure. Journal of Dairy Science, 70, 407-413.

[4] Gushiken, M. and Akisaka, M. (2004) A survey of calcaneus bone mineral density related to physique in young females and comparison of the findings to those of elderly females in Okinawa. The Journal of Education and Health Science, 49, 239-247.

[5] Japan Osteoporosis Foundation (2000) This handbook for preventing osteoporosis is based on the Health and Medical Service Act for the Aged. 2nd edition. Japan Medical Journal, 1-19, 21-37, 39-59, 61-85.

[6] Yokouchi, J., Ando, D., Ono, Y., Ozaki, Y., Asakawa, K., Kitagawa, J., Nakahara, Y. and Koyama, K. (2003) The relationship between calcaneal quantitative ultrasound parameters and anthropometric measures in university women. Japanese Journal of Physical Fitness and Sports Medicine, 52, 639-646.

[7] Tomita, N. and Akisaka, M. (2007) A study on the relationship between bone mineral density and dietary habits and regular exercise activity of junior college dietetics students. The Journal of Education and Health Science, 52, 212-224.

[8] Nakata, H., Okazaki, N., Yagita, K., Ohtsuki, S., Satoh, H. and Mimura, K. (2003) The relationship between ultrasound calcaneal bone mass, physique, and daily habits in women's junior college students. The Journal of Educa- tion and Health Science, 49, 155-162.

[9] Dawson-Hughes, B., Harris, S.S., Krall, E.A., Dallal, G.E., Falconer, G. and Green, C.L. (1995) Rates of bone loss in postmenopausal women randomly assigned to one of two dosages of vitamin D. The American Journal of Clinical Nutrition, 61, 1140-1145.

[10] Yahata, Y., Aoyagi, K., Okano, K., Yoshimi, I., Kusano, Y., Kobayashi, M., Moji, K. and Takemoto, T. (2002) Metacarpal bone mineral density, body mass index and lifestyle among postmenopausal Japanese women: relationship of body mass index, physical activity, calcium intake, alcohol and smoking to bone mineral density: The HizenOshima study. The Tohoku Journal of Experimental Medicine, 196, 123-129.

[11] Kameda, T., Mano, H., Yuasa, T., Mori, Y., Miyazawa, K., Shiokawa, M., Nakamaru, Y., Hiroi, E., Hiura, K., Kameda, A., Yang, N.N., Hakeda, Y. and Kumegawa, M. (1997) Estrogen inhibits bone resorption by directly inducing apoptosis of the bone-resorbing osteoclasts. The Journal of Experimental Medicine, 186(4), 489-495.

[12] Hirose, K., Tomiyama, H., Okazaki, R., Arai, T., Koji, Y., Zaydun, G., Hori S. and Yamashina, A. (2003) Increased pulse wave velocity associated with reduced calcaneal quantitative osteo-sono index: possible relationship between atherosclerosis and osteopenia. The Journal of Clinical Endocrinology \& Metabolism, 88, 2573-2578.

[13] Ishiguro, N., Miyatani, M., Kanehisa, H., Kuno, S. and Fukunaga, T. (2003) Relationship between walking steps during daily life and both the bone intensity of calcaneus and muscle thickness of the lower leg in elderly men and women. Japanese Journal of Physical Fitness and Sports Medicine, 52 (Suppl), 127-132.

[14] Tsuda-Futami, E., Hans, D., Njeh, C.F., Fuerst, T., Fan, B., Li, J., He, Y.Q. and Genant, H.K. (1999) An evaluation of a new gel-coupled ultrasound device for the quantitative assessment of bone. The British Journal of Radiology, 72, 
691-700.

[15] Ikeda, Y., Iki, M., Morita, A., Kajita, E., Kagamimori, S., Kagawa, Y. and Yoneshima, H. (2006) Intake of fermented soybeans, natto, is associated with reduced bone loss in postmenopausal women: Japanese Population-Based Osteoporosis (JPOS) Study. The Journal of Nutrition, 136, 1323-1328.

[16] Morita, A., Iki, M., Dohi, Y., Ikeda, Y., Kagamimori, S., Kagawa, Y., Matsuzaki, T., Yoneshima, H. and Marumo, F. (2004) Prediction of bone mineral density from vitamin D receptor polymorphisms is uncertain in representative samples of Japanese Women. The Japanese Population-based Osteoporosis (JPOS) Study. International Journal of Epidemiology, 33, 979-988.

[17] Demura, S. (2007) Health and sports science research method. Kyorin-shoin, Tokyo, 65-86.

[18] Elgán, C. and Fridlund, B. (2006) Bone mineral density in relation to body mass index among young women: a prospective cohort study. International Journal of Nursing Studies, 43, 663-672.

[19] Cohen J (1988) Statistical power analysis for the behavioral sciences 2nd. Lawrence Erlbaum Assoc Inc.

[20] Lloyd, T., Andon, M.B., Rollings, N., Martel, J.K., Landis J.R., Demers, L.M., Eggli, D.F., Kieselhorst, K. and Kulin,
H.E. (1993) Calcium supplementation and bone mineral density in adolescent girls. The Journal of the American Medical Association, 270, 841-844.

[21] Dawson-Hughes, B., Harris, S.S., Krall, E.A. and Dallal, G.E. (1997) Effect of calcium and vitamin D supplementation on bone density in men and women 65 years of age or older. The New England Journal of Medicine, 337, 670-676.

[22] Dawson-Hughes, B. (1996) Calcium and vitamin D nutritional needs of elderly women. The Journal of Nutrition 126, 1165s-1167s.

[23] Gallagher, J.C., Riggs, B.L., Eisman, J., Hamstra, A., Arnaud, S.B. and DeLuca, H.F. (1979) Intestinal calcium absorption and serum vitamin D metabolites in normal subjects and osteoporotic patients: effect of age and dietary calcium. The Journal of Clinical Investigation, 64, 729-736.

[24] Sanada, K., Sato, S., Kambe, Y., Kuchiki, T., Bunya, T. and Ebashi, H. (1999) Relationships between the gastrocnemius or soleus muscle thickness and the calcaneal bone stiffness in post menopausal women. Japanese Journal of Physical Fitness and Sports Medicine, 48, 291-300. 